J. Japan. Assoc. Min.

Petr. Econ. Geol.

73, 380-387, 1978 .

\title{
HYDROGEN ISOTOPE STUDY ON THE CONTACT AUREOLE OF THE PLUTONIC MASS IN THE VICINITY OF THE SASAGO TUNNEL, YAMANASHI PREFECTURE, JAPAN
}

\author{
YoshtMasu KURODA \\ Department of Geology, Shinshu University, Matsumoto, Japan \\ TAKESHI KuBOTA \\ Shimura High School, Itabashi-ku, Tokyo, Japan \\ TETsuro SuzuokI \\ Marine Department, Meteorological Agency, Otemachi, Chiyada-ku, Japan \\ and Sadao Matsuo \\ Department of Chemistry. Tokyo Institute of Technology. O-okayama, Meguro-ku. Tokyo, Japan
}

\begin{abstract}
Several pairs of coexisting biotite and hornblende were separated from the rocks of the granodioritic pluton, and their $\delta D$ and $\mathrm{FeO} /(\mathrm{FeO}+\mathrm{MgO})$ were determined. These rocks belonged to the cquilibrium type defined by Kuroda et al. (1977a) and the $\delta D$ value of the aqueous fluid in the magma was estimated to be about $-30 \%$.

Contact aureole of the pluton were divided into four zones, the biotite zone, the first cordierite zone, the second cordierite zone and the $K$-feldspar zone. The $\delta D$ values of the bulk metamorphic rocks derived from pelitic sediments in the biotite and first cordierite zones were uniform, i.e., -56 to $-64 \%$. These values are also the same as those of the nonmetamorphosed pelitic rocks from the same formation in the different locality. On the contrary, those in the second cordierite and $K$-feldspar zones were scattered from -48 to $-76 \%$, and the $\delta D$ values of biotites from the same rocks showed also a wide range from -48 to $-80 \%$. The wide range of $8 D$ values from these high grade rocks may be a reflection of a complicated behaviour of hydrogen isotope exchange in the contact metamorphism.
\end{abstract}

\section{INTRODUGTION}

We have emphasized the presence of two kinds of of granitic rock masses in terms of $\mathrm{D} / \mathrm{H}$ fractionation between coexisting biotite and hornblende, i.e., the equilibrium type and the disequilibrium type (Kuroda et al. 1974, 1975, 1977a, etc.). In the former type $\mathrm{D} / \mathrm{H}$ distribution between them is followed by the Suzuoki-Epstein's experimental result (Suzuoki and Epstein 1976), whereas in the latter type it is quite different from the experimental result. We have explained the origin of the occurrence of two types based on the content and state of water in granitic magmas (Kuroda et al., 1977a, 1978). If a magma is supersaturated with water and then contains the aqueous fluid (free phase of water), the granite crystallized out from the magma would be the equilibrium type. On the contrary, if a magma does not contain 
enough water to make the aqueous fluid but contains only the dissolved water in the melt, the granite would be the disequilibrium. type. The water to make the aqueous fluid in granitic magmas may be derived from unconsolidated sedimentary country rocks.

From this point of view, D/H investigation on minerals and rocks from both a granitic mass and surrounding metamorphic sedimentary rocks is worthwhile to conduct. The papers such as Shieh and Taylor (1969) and Magaritz and Taylor (1976) were the ealiest studies of this type. Although they provided the useful data, the discussion of the behaviour of water in granite magma intrusions is not fully convincing, because of the lack of the information on the chemistry dependence of $\mathrm{D} / \mathrm{H}$ fractionation. We have investigated the $\mathrm{D} / \mathrm{H}$ ratios on minerals from both metamorphic and plutonic rocks in the Ryoke belt (Kuroda et al. $1977 \mathrm{~b}$ ), but in that case we could not discuss the behaviour of water in both metamorphic and plutonic rocks, because: the granitic rocks belonged to the disequilibrium type. Therefore, the present paper gives the first information on such problem.

\section{General Geology}

The present district is composed of the hornfelses and the granitic rocks. The outline of geology and sampling sites are

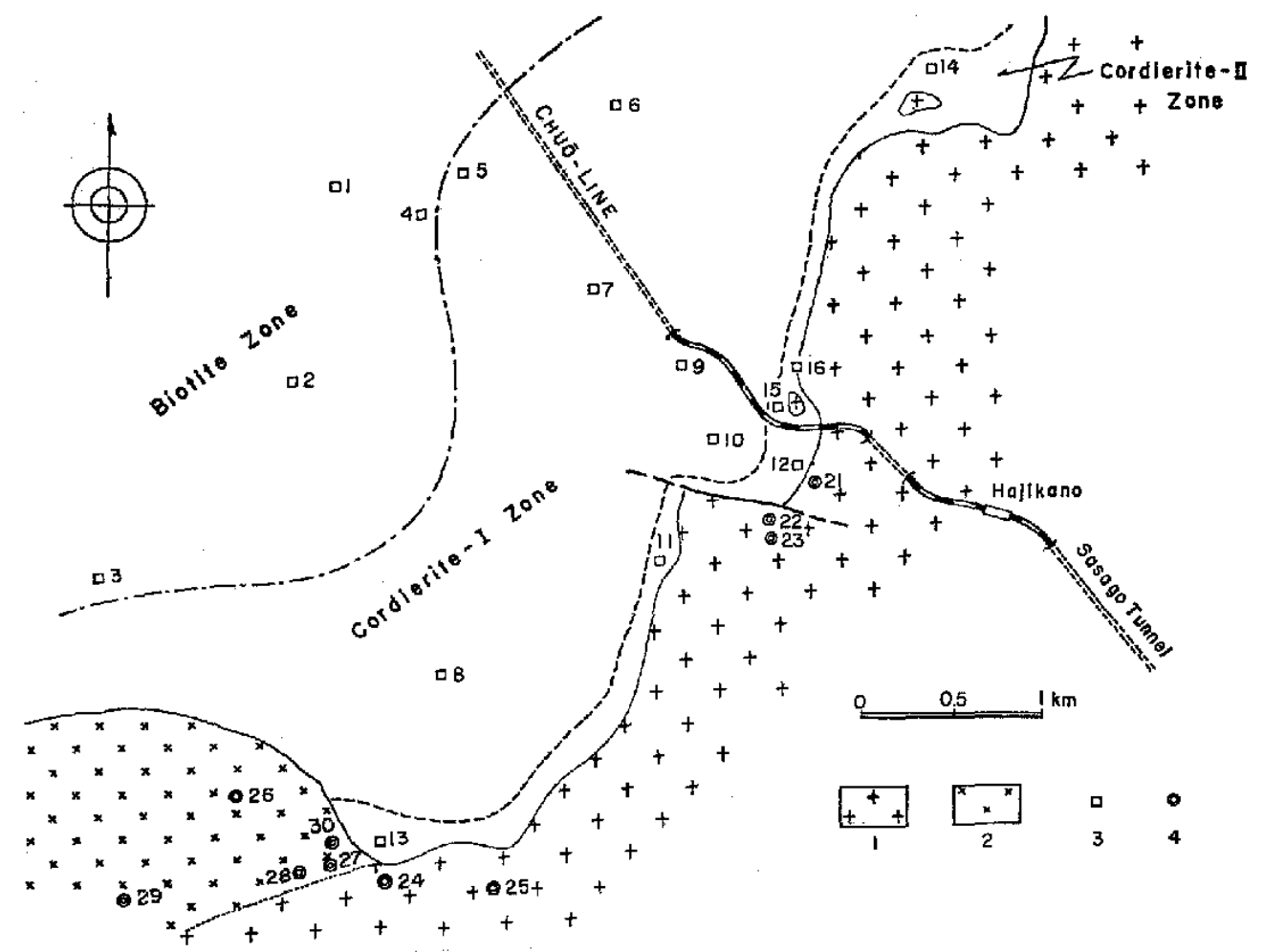

Fig. 1. Geological map and sampling sites.

1: granite granodiorite, 2: quartz-diorite, 3: sampling sites of the metamorphic rocks, 4: sampling sites of the plutonic rocks.

The attached numbers to the sampling sites are the same as those in Tables 1 and 2 . 
shown in Fig. 1.

The granodiorite mass of this district was considered to be intruded in the Miocene by Kato (1968). On the other hand, Fujimoto et al. (1958) and Fujimoto (1978) divided the plutonic rocks into two groups, granodiorite and quartzdiorite, and made the former to be the Cretaceous intrusion and the latter to be the Miocene intrusion. However, the absolute age of the granodiorite was determined to be about $10 \times 10^{8} \mathrm{y}$. by K-Ar method (Kawano and Ueda 1966), by $\mathrm{Rb}-\mathrm{Sr}$ mineral age for biotites (Hayase et al. 1970) and also by the fission track age of apatite (Suzuki 1977). The plutonic mass studied here is divided into two parts. The one, the main part, is made of granite-granodiorite, and the other, the western part, of quartz-diorite. The boundary between them is not distinct and it seems to be transitional. Some parts of the quartz-diorite contain both clinopyroxene and orthopyroxene with hornblende and biotite.

The country rocks are originally sed- imentary rocks, consisting of pelitic rock with sandstone intercalations and a small amount of chert, which are considered to be the Setogawa Group, Paleogene. The general strike of the formation is WNW-ESE and the dip is steep generally to NNE, and the microfolding axes pitch to SE. This structure is nearly at right angles to the boundary of contact with the the granitic mass.

The country rocks are metamorphosed into the hornlefses by the contact effect of the granitic rocks. The metamorphic aureole is divided into four zones across the general trend of the formation, the biotite zone, the first coriderite zone, the second cordierite zone and the $\mathrm{K}$-feldspar zone, by the mineral paragenesis of the pelitic rocks. The boundary of the biotite zone and the first cordierite zone is defined by the appearance of the first cordierite, which is the porphyroblast containing minute dusty crystals of biotite, clayey minerals, carbonaceous matters etc. The isograd of the first cordierite is situated at

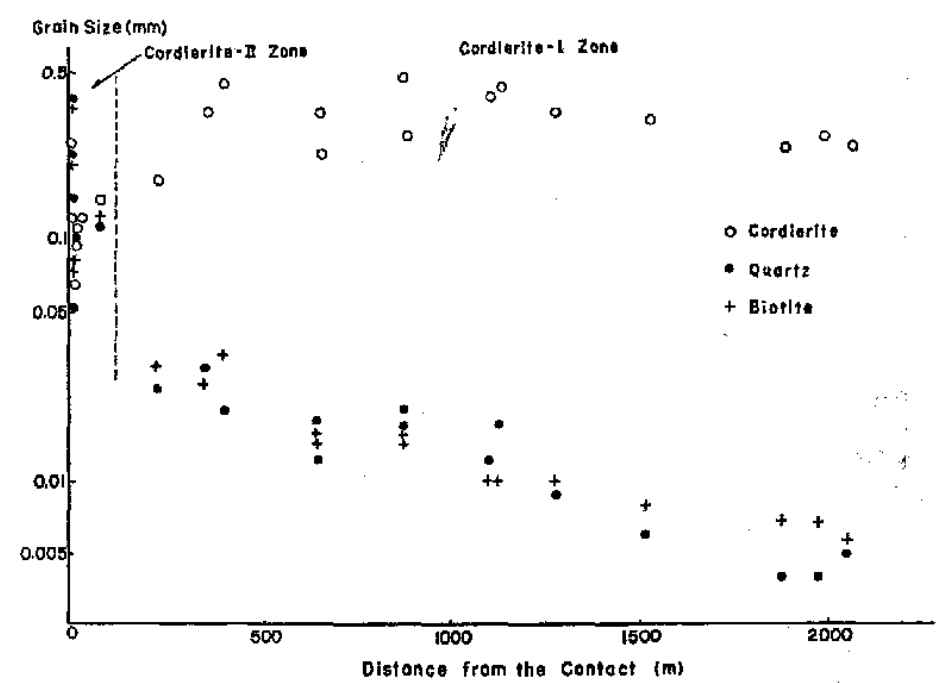

Fig. 2. Variation of the grain size of cordierite, quartz and biotite with the distance from the contact. 
the distance of 1.4-2.2 $\mathrm{km}$ from the contact. The boundary between the first and the second cordierite zones is the isograd of the second cordierite, which is the clean crystal free from the dusty inclusions. Mineral parageneses of both zones are almost the same to each other, but in the first cordierite zone chlorite is sometimes seen and muscovite is common, whereas in the second cordierite zone chlorite is scarce and muscovite is less. Furthermore, the grain size of biotite and quartz from the second cordierite zone becomes large abruptly as seen in Fig. 2. The width of the second cordierite zone is about 100 to $300 \mathrm{~m}$ from the contact. Quite near the contact $(\sim 1$ m) K-feldspar bearing hornfelses are sometimes found. The rocks contain K-feldspar, plagioclase, quartz, biotite and cordierite, but do not contain sillimanite and muscovite.

It is difficult to estimate the temperature of metamorphism. However, the biotite and first cordierite zones may belong to greenschist facies to epidote-amphibolite facies, and the second cordierite and $\mathrm{K}$ feldspar zones to epidote-amphibolite to amphibolite facies.

\section{D/H Measurement on the Meta- MORPHIC ROCKS}

We measured $\mathrm{D} / \mathrm{H}$ ratios of water extracted from the bulk metamorphic rocks of pelitic composition, of which four are from the biotite zone, six from the first cordierite zone, four from the second cordierite zone and two from the K-feldspar zone. The biotites were separated from the same metamorphic rocks of the second cordierite zone and the K-feldspar zone mentioned above and were also analyzed. Biotites from the rocks of the biotite and
Table 1. Analytical results of bulk rocks and biotites of the hornfelses.

\begin{tabular}{|c|c|c|c|c|c|}
\hline & \multicolumn{2}{|c|}{ bulk rock } & \multicolumn{3}{|c|}{ biotite } \\
\hline & $\mathrm{H}_{2} \mathrm{O}$ (wt $\Rightarrow$ & $\delta \mathrm{D}\langle \%)$ & $\mathrm{H}_{z} \mathrm{O}$ (wt & $\delta \mathrm{D}(\%)$ & $x_{\mathrm{Fe}}$ \\
\hline 1 & 2.50 & -58.4 & & & \\
\hline 2 & 2.00 & -57.0 & & & \\
\hline 3 & 2.43 & -59.3 & & & \\
\hline 4 & 1.61 & -63.9 & & & \\
\hline 5 & 1.82 & -60.9 & & & \\
\hline 6 & 1.28 & -60.3 & & & \\
\hline 7 & 2.50 & -59.6 & & & \\
\hline 8 & 1.73 & -60.8 & & & \\
\hline 9 & 2.97 & -63.5 & & & \\
\hline 10 & 1.34 & -56.1 & & & \\
\hline 11 & 1.56 & -70.6 & 3.89 & -61.5 & 0.39 \\
\hline 12 & 0.84 & -50.2 & 4.92 & -48.4 & 0.43 \\
\hline 13 & 1.00 & -66.8 & 4.20 & -92.4 & 0.51 \\
\hline 14 & 1.13 & -76.0 & 4.14 & -79.7 & 0.42 \\
\hline 15 & 1.30 & -48.0 & 3.11 & -56.3 & 0.58 \\
\hline 16 & 1.30 & -62.3 & 3.28 & -61.7 & 0.58 \\
\hline
\end{tabular}

Note: $1-4$, biotite zone, 1 (No. 76092306), 2 (No. 76092011), 3 (No. 76101201) and 4 (No. 76062801): 5-10, 1st cordierite zone, 5 (No. 76051514), 6 (No.76051712), 7 (No.76072001), 8 (No. 76101405), 9 (No.76071705) and 10 (No. 76050904); 11-14, and cordierite zone, 11 (No. 76051602), 12 (No. 76071501), 13 (No.76101211 B) and 14 (No. 76051504); 15-16, K-feldspar zone, 15 (No, 76062903) and 16 (No. $76050804 \mathrm{~A}$ ).

first cordierite zones were too tiny to separate. The results of these analyses are presented in Table 1 , and the localities are shown in Fig. 1 with the same sample numbers.

The bulk rocks analyzed were usually powdered under 200 mesh and washed with water. All the data presented in Table 1 are for the samples after washing with water. We compared the $\delta D$ and water content of the samples before and after washing. For example, Nos. 4, 5 and 6 samples in Table 1 show $-69.2 \%,-65.5 \%$ and $-58.3 \%$ in $\delta D$, and $1.99 \%, 1.91 \%$ and $1.38 \%$ in water content, before washing, respectively. This shows that the $\delta D$ value becomes somewhat higher and the 
water content lower after washing, but the difference is not so large. Such difference is possibly derived from the removal of very fine powders, which are considerably rich in the clayey fraction, by washing with water. We usually used the washed powders for the bulk rock analyses, because of the difficulty of the extraction of water from a very fine powder. A very fine powder sometimes flies off in a vacuum.

Water contents of the bulk rocks become lower with the increase of metamorphic grade, though the relationship between the distance from the contact and water content is not necessarily correlated.

$\delta D$ values of the bulk rocks from the biotite zone and the first cordierite zone are in the narrow range, i.e., from -57 to $-64 \%$, whereas those from the second cordierite zone and the $\mathrm{K}$-feldspar zone are scattered from -48 to $-76 \%$. The $\delta D$ values of the biotites from the hornfelses of the second cordierite zone and the K-feldspar zone are comparable to those of the bulk rocks as

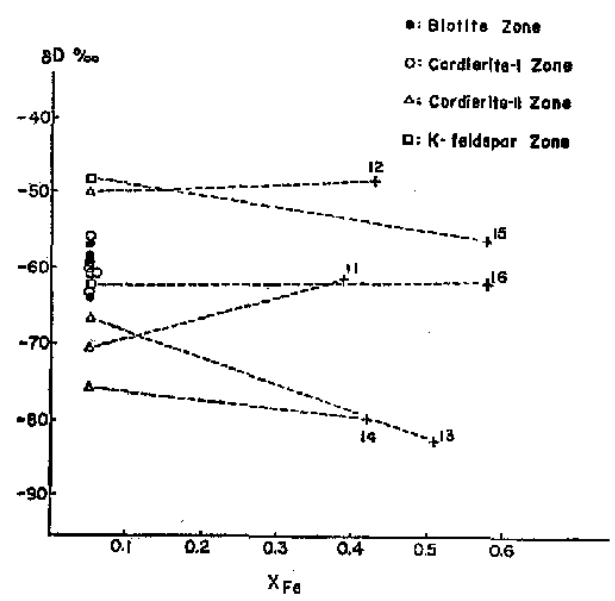

Fig. 3. $\delta D$ values for the bulk metamorphic rocks from each zone and relationship between $\delta D$ and $X_{\text {Fo }}$ for the biotites. The attached numbers to the biotites are the same as those in Table 1 , Broken lines connect the same samples. seen in Fig. 3. This is natural, because the most of the water extracted from the bulk rocks comes from the biotites. If the biotites obey the Suzuoki-Epstein's experimental result, the range of $\delta D$ values of the biotites after calculation for $X_{\mathrm{Fe}}=0$ is -24 to $-56 \%$. This means that the range of $\delta D$ values of the ambient waters for the biotites is -10 to $-44 \%$ provided the temperature of the metamorphism of the zones is 350 $450^{\circ} \mathrm{C}$. As stated before (Kuroda et al. $1977 \mathrm{~b}) \delta D$ values of biotites from metamorphic rocks from the Komagane district, the Ryoke belt, central Japan, were also scattered as the metamorphic grade increases.

There can not be found non-metamorphic original sedimentary pelitic rocks in this field. Three specimens of pelitic rock were collected from about $10 \mathrm{~km}$ east from this field, where seems to be free from the contact metamorphism. The formation including these rock samples is correlated to be also the Setogawa Group, and these rocks have no biotite under the microscope. The water content and $\delta D$ value of these samples are as follows: No. $78031104(2.10 \%$; $50.4 \%)$, No. $780831103(2.68 \%,-61.1 \% 0)$ and No. $780831102(2.75 \%,-58.9 \%)$. These values are similar to those from the biotite and first cordierite zones of this district. Therefore, it can be said that $\delta D$ value of about $-60 \%$ is valid for the water in the pelitic rocks of the Setogawa Group and its weakly metamorphosed derivatives.

\section{D/H Measurement on the Granitic Rocks}

Five pairs of coexisting biotite and hormblende from the granodiorites were separated and analyzed. Three biotites and four hornblendes, among which two 
Table 2. Analytical results of biotite and hornblende from the plutonic rocks.

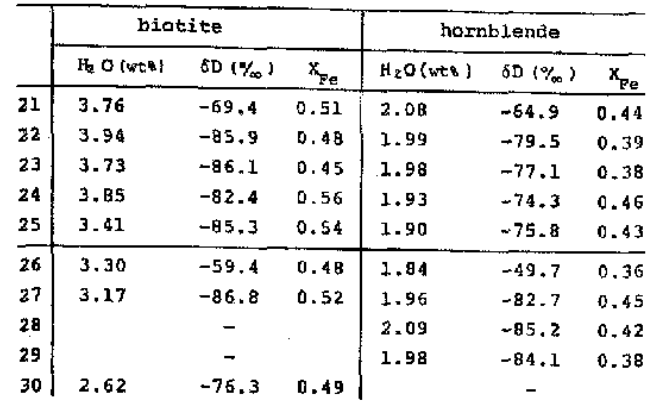

Note: 21-25, granodiorite, 21 (No. 76092101), 22 (No. 76092104), 23 (No. 76092105), 24 (no. 77052103) and 25 (No.7752009), 26-30, quartz-diorite, 26(No. 760101204), 27 (No. 77052111), 28 (No. 77052105), 29 (No. 77052313) and 30 (No. 77052004).

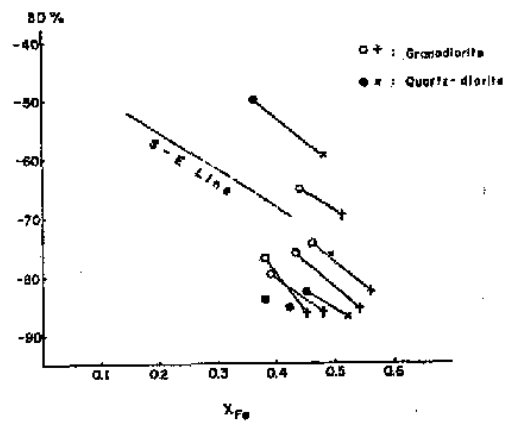

Fig. 4 Relationship between $\delta D$ and $X_{\mathrm{F} \theta}$ of coexisting biotite and hornblende in the plutonic rocks.

(Nos. 26 and 27) are paired, from the quartzdiorites were also separated and analyzed. They are presented in Table 2 and are illustrated in Fig. 4.

As clearly recognized from this figure, these rocks belong to the typical equilibrium type of Kuroda et al. $(1975,1977 \mathrm{a})$. The one pair from the quartz-diorite (No. 26) shows the highest $\delta D$ value, but there can not be found any particular difference between the granodiorite and quartz-diorite. The maximum difference between the highest and the lowest values of $\delta D$ after correction to $X_{F \theta}=0$ is about $30 \mathscr{K}_{0}$, the range being from -30 to $-61 \%$, which may correspond to the temperature difference of about $300^{\circ} \mathrm{C}(800$ $\sim 500^{\circ} \mathrm{C}$ ), if the aqueous fluid was uniform in the mass. Then the $\delta D$ value of the aqueous fluid may be estimated to be about $-30 \%$, provided the pair of the highest $\delta D$ value was isotopically equilibrated at 700 $\sim 800^{\circ} \mathrm{C}$ using our unique method (Kuroda et al. 1977a).

\section{Discussion}

As discussed previously by Kuroda et al. $(1977 \mathrm{a}, 1978)$, it can be considered that there are two states of water in granitic magmas, the dissolved water in melt and the aqueous fluid (free phase of water). If a magma is supersaturated with water it may contain the aqueous fluid together with the dissolved water and the rock crystallized from such magma would be the equilibrium type rocks. If a mgma is not saturated with water, it may contain only the dissolved water and the rocks crystallized from that magma may be the disequilibrium type rocks.

Since the granodiorites and quartzdiorites studied here are the equilibrium type rocks, we can estimate the $\delta D$ value of the aqueous fluid in the magma according to the Suzuoki-Epstein's experimental formula (see Kuroda et al. 1977a), if the temperature of crystallization or equilibration with respect to hydrogen isotope exchange is known.

Provided that the maximum temperature of equilibration in terms of hydrogen isotope exchange between the hydrous silicates and the aqueous fluid can be estimated to be $700 \sim 800^{\circ} \mathrm{C}$ for No. 26 pair in Table 2, the minimum temperature 
would be $450 \sim 550^{\circ} \mathrm{C}$ for Nos. 22,23 and 27 pairs and then the $\delta D$ value of the aqueous fluid in the magma would be estimated to be about $-30 \%$, which is quite the same as that of the southern Kitakami mountainous district first reported by Kuroda et al. (1974). That value has been also recognized for the aqueous fluid in some Cretaceous granitic masses besides the Kitakami district (Kuroda et al. unpublished). Therefore, $\delta D$ value of the aqueous fluid, $-30 \%$, may have a special meaning in granite magmatism, which is not yet known well.

When we consider that the aqueous fluid in granitic magmas is derived from the sedimentary country rocks, the water (aqueous fluid) with the $\delta D$ value, $-30 \%$, in this case, should come from the sedimentary country rocks, which have been metamorphosed into hornfelses afterwards. However, $\delta D$ value of water from the country sedimentary rocks in this case is about $-60 \%$ as mentioned above. Our preliminary work on the Japanese pelitic rocks also shows that $\delta D$ values of waters from those rocks are from -50 to $-80 \%$. These values including $-60 \%$ in this case seem to be reasonable values for marine pelitic sediments. Then, there is a discrepancy between $\delta D$ value of the aqueous fluid of the granitic magma, $-30 \%$, and that of the country rocks, $-60 \%$. If the aqueous fluid was derived from the country rocks, it should be assumed that the dissolved water was rich in deuterium, i.e,, by far higher than $-30 \%$. However, such higher $\delta D$ value can not be considered for the dissolved water in granitic magmas, because $\delta D$ values of mica and amphibole are not so higher even in the disequilibrium type granitic rocks. Thus the discrepancy is still problematical.

It is also not easy to explain the origin of divergency of $8 D$ values of the bulk rocks and biotites from the second cordierite and K-feldspar zones, but a possible explanation is as follows. The rocks and biotites with the lower $\delta D$ value in both zones were equilibrated with the water of $-60 \%$ which was dehydrated from non-metamorphosed original sedimentary rocks. On the contrary, those with higher $\delta D$ value were equilibrated with the residual water of the granitic magma, which would become higher in $\delta D$ value after hydrous silicates with lower $\delta D$ values were crystallized out. The second cordierite and $\mathrm{K}$-feldspar zones are so narrow and close to the contact that various effects on the contact metamorphism and later magmatism would be superimposed and then the diversity of $\delta D$ value of the rocks in the higher grade zones was occurred.

\section{AGKNOWLEDGEMENT}

A part of the expense of this study was defrayed by the Scientific Grant of the Ministry of Education, Science and Calture of Japan.

\section{REFERENCES}

Fujimoto, U., Shibata, H., Yoshitake, H. and Oki, Y. (1958), Geology of the neighbourhood of Mt. Kogarasu, Yamanashi Prefecture, with special reference to plutonic rocks. Jour. Geol. Soc. Japan, 64, 250-257.

Fujimoto, U. (1978), Comparison of Late Cretaceous granite and Miocene quartz-diorite in Yamanashi Prefecture. Abstract, Ann. Meet. 85th, Geol. Soc. Japan, 313.

Kato, Y. (1968), On the Tertiary granitic rokes around Kohu'basin, Yamanashi Prefecture. Jour. Japan. Assoc. Min. Petr. Econ. Geol., 59, $21-40$

Kawano, Y. and Ueda, Y. (1966), K-A dating on the igneous rocks in Japan (IV)-Granitic rocks in northeastern Japan. Jour. Japan. Assoc. Min. Petr. Econ. Geol, 56, 41-55.

Kuroda, Y., Suzuoki, T., Matsuo, S. and Kanisawa, S. (1974), D/H fractionation of coexisting 
biotite and hornblende in some granitic masses. Jour. Japan. Assoc. Min. Petr. Econ. Geol., 69, 95-102.

\footnotetext{
$\longrightarrow$, $-\longrightarrow$, $\longrightarrow$ (1975), D/H fractionation of coexisting biotite and hornblende in some granitic masses-A supplement. Jour. Japan. Assoc. Min. Petr. Econ, Geol., 70, 352-362.
$\longrightarrow,-\longrightarrow-(1977$ a), Equilibrium and disequitibrium type of the Japanese granitic rocks derived from hydrogen isotope study. Plutonism in relation to volcanism and metamorphism, 7th CPPP Meating Japan, 184-193.
- Fujimoto, K., Suzuoki, T. and Matsuo, S. (1977b), D/H ratios of hydrous silicates from the metamorphic and granitic rocks in the Iga-Ueno and Komagne districts of the Ryoke, belt. Jour. Geol. Soc. Japan, 83, 353- 357.
- Suzuoki, T. and Matsuo, S. (1978), Hydrogen isotope fractionation in granitic magma genesis. Abstr. Papers, Intern. Geodynamics Conf. West. Pacific and Magma Genesis, Tokyo, 282-283.

Magaritz, M. and Taylor, H.P. Jr. (1976), ${ }^{18} \mathrm{O} /{ }^{10} \mathrm{O}$ and $\mathrm{D} / \mathrm{H}$ studies along a $500 \mathrm{~km}$ traverse across the Coast Range batholith and its country rocks, central British Columbia. Canad. J. Eavth Soi, 13, 1514-1536.

Savin, S.M. and Epstein, S. (1970), The oxygen and hydrogen isotope geochemistry of clay minerals. Geochim. Cosmochim. Acta, 34, 25-42.

Shieh, Y.N. and Taylor, H.P. Jr. (1969), Oxygen and hydrogen isotope studies of contact metamorphism in the Santa Rosa range, Nevada and other areas. Contrib. Mineral. Petrol., 20, 306-356.

Suzuki, T. (1977), Some fission track ages of accessory apatite and sphene from granitic rocks around Kofu basin, central Japan. Sci. Rep. Tokyo Kyoiku Daigaku, Sec. C, 12, 121, $37-45$.

Suzuoki, T. and Epstein, S. (1976), Hydrogen fractionation between $\mathrm{OH}$-bearing silicate minerals and water. Geochim. Cosmochim. Acta, 40, 1229-1240.

Yamanashi Prefecture (Hayase, I. et al.) (1970), Explanatory text of the Geological Map of the Yamanashi Prefecture.

\title{
山梨県, 筈子トンネル付近の深成岩体とその接触变成带における水素同位体的研究
}

\author{
黒田 吉益·久保田剛司・鈴置 哲朗・松尾 禎士

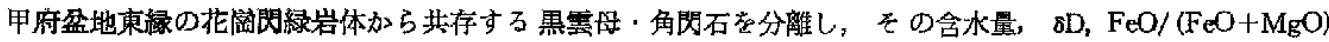

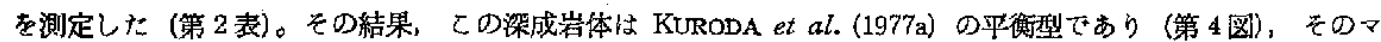 \\ ダマが含んでいた aqueous fluid（KURODA et al. 1978）の8D は約 -30\% と推定できた。 \\ との深成岩体は瀬戸川層群の構造を切って貫入し，それをホルンつェルス化している。ホルンフェルスは黒零

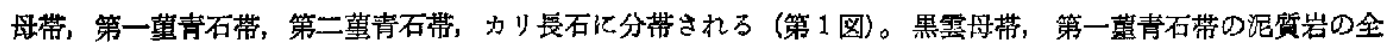

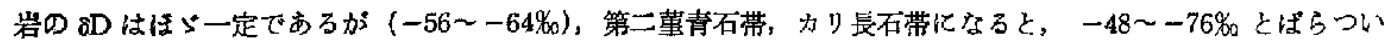

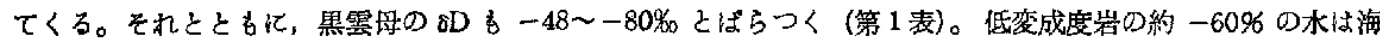

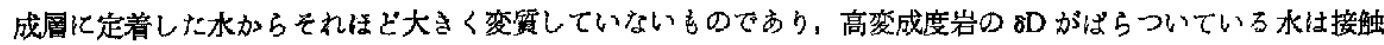 \\ 部近くのふくざつな現象学反映しているせいである。

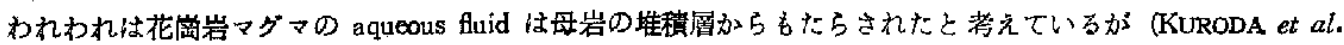

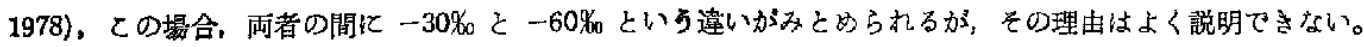

